Vol.16, No. 61, October 2021,1009-1023

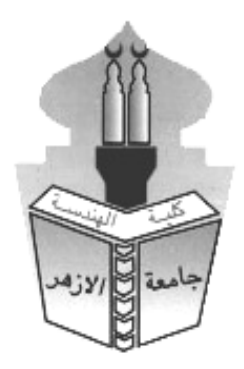

\title{
FLOODS HAZARDS ASSESSMENT BY INTEGRATING HYDROLOGIC MODELING AND A GEOGRAPHIC INFORMATION SYSTEMS (MULTI- CRITERIA DECISION TECHNIQUE)
}

\author{
Hany G. I. Ahmed \\ Civil Eng.Dept.,Faculty of Engineering,Al-Azhar University,Cairo,Egypt \\ Received :26 July 2021 Accepted:1 Sepetmber 2021
}

\begin{abstract}
:
The protection of urban areas located on the eastern side of the Nile River in Upper Egypt, which is highly exposed to flood hazards, represents one of the most important priorities of the Egyptian state to achieve the future of sustainable urban development for Egypt's Vision 2030. This research deals with two main steps: The first step is to combine a hydrological model (HEC-1) with a geographic information system (GIS) to obtain high-caliber hydrological modeling. The second step is to create a flood hazard map by GIS- Model Builder based on the multi-criteria decision analysis method in geographic information systems (GIS-MCDA) based on the application of the Analytic Hierarchy Process (AHP). The research flagged out that the obtained results would most probably assist decision-makers Creating a clear vision for sustainable development in the region. In addition to that, the research highlighted the importance of implementing flood hazards management activities to ensure the environmental rehabilitation of watersheds to avoid flood disasters.
\end{abstract}

Keywords: Geographic Information Systems (GIS); Model Builder; Hydrologic Modelling (HEC-1); multi-criteria decision analysis (MCDA); Flood Hazard Map (F.H.M).

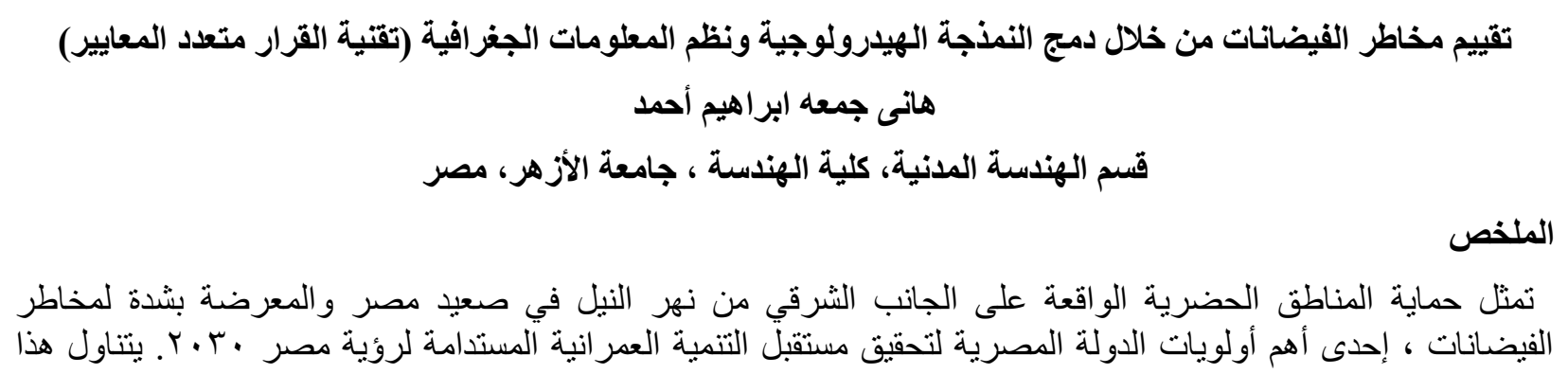


البحث خطوتين رئيسينين: الخطوة الأولى هي دمج نموذج هيدرولوجي (HEC-1) مع نظم المعلومات الجغر افية (GIS)

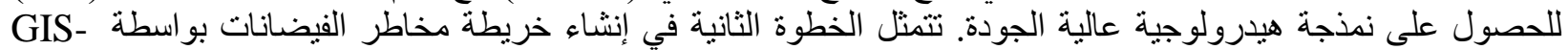
بناءً على طريقة تحليل القرار متعدد المعايير في أنظمة المعلومات الجغر افية (GIS-MCDA) اعتمادا على تطبيق عملية التسلسل الهرمي التحليلي (AHP). تم التخطيط لمنهجية البحث لتشمل خمس تحقيقات ( التحقيقات النظرية

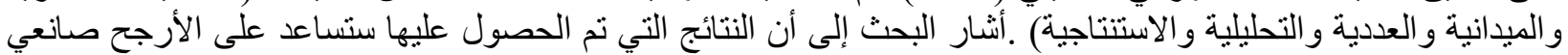

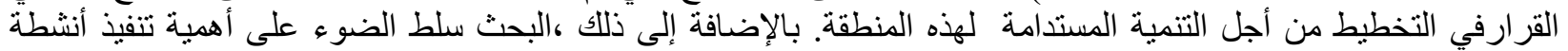

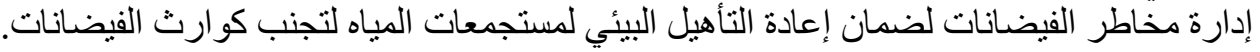

\section{Introduction}

Floods like any other natural phenomenon that have positive impacts if they are wisely managed. However, they may have many negative impacts if they are handled without enough preparedness. The dry and mountainous nature of the Middle East emphasizes the fact that management of this phenomenon is extremely important not only to avoid their negative impacts but also to make use of such freshwater resources. Floods are considered one of the worst natural disasters. During the stage from 1995 to 2017, 2.3 billion people were affected by these floods. Nearly 157,000 people were passed away due to this natural hazard. Furthermore, financial losses were valued at more than 662 billion dollars (Wahlstrom and Sapir, 2017). To reduce flood hazards, flood-subjected regions over various return periods are very essential to be precisely specified (Billa, et al, 2006). Moreover, drawing flood-risk maps is one of the essential precautions against flood disasters. (Bubeck, et al, 2012). Over the past few decades, flood modeling using the hydrological and hydraulic modeling programs has evolved dramatically with the advent of GIS and satellite-derived remote sensing imagery and the emergence of highresolution digital elevation models (DEMs) (Song, Y, et al, 2018). Mapping hazardous zones are very useful for the assessment and management of flood hazards. These maps are helpful for flood protection and land-use planning (EU IPA 2010 TWINNING PROJECT, 2010). The Committee on Floodplain Mapping Technologies (2007) prefers utilizing the geographic information system (GIS) to produce flood risk maps due to its superiority in analysis, manipulating, and mapping of huge spatial data. Gericke and Plessis (2012) compared the watershed characteristics as collected by the ArcGIS with manual calculations. they concluded that the success of applying the ArcGIS in estimating these parameters but of course the ArcGIS is superior due to its quickness.. Kourgialas and efrerer (2016) have assessed and mapped the flood risk in the island of Crete in Greece using data about the rainfall, topography, and flood flow. The relative weights of these parameters were estimated based on subjective opinions. Thereafter, they used the map algebraic functions available in ArcGIS to map the flood risk using five classes of symbols (from very high to very low). Al-Abadi et al. (2016) used only topographic characteristics to assess flood risk in a watershed in the south of Iraq. According to De Brito and Ever (2016), the Analytic Hierarchy Process (AHP), one of the pairwise comparing methods, is the most common multiple criteria assessment method. That is because it is straightforward, understandable, and allows subjective participation of the experts. AHP molders the complex multi-criteria into a hierarchy process. It originates the importance of each criterion, to the other corresponding criteria. The multi-criteria decision analysis method, based on geographic information systems (GIS-MCDA), is the method used most widely in geographic, schematic, and applied studies. In urban areas, flood hazard modeling using this 
method is appropriate. Calculating the weight of each criterion is performed through the Analytic Hierarchy Process (AHP). (Kazakis, et al, 2015; Khabat, et al 2016; Somaiyeh and Mehran, 2017; Andi, et al, 2017; Olga, et al 2018.) However, ArcGIS is a very powerful software but it is frequently needs to use long series of data analysis steps. In these situations, ModelBuilder is very useful to automate these processes. (Ghabayen and Salha (2013); Omran et al. (2011); Magesh and Chandrasekar (2012); Elmoustafa et al. (2015)). The technique that applied in this research will contribute to the planning of safe cities from the flood risk and help in selecting the best protection structures at the lowest possible cost.

\section{Study area}

The technique used in this research will be applied to the village of Hegaza-Bahari, which is one of the villages of Qus Center in the Governorate of Qena in Upper Egypt. The area of the village of Hegaza-Bahari is $17865292.1299 \mathrm{~m}^{2}$ according to the administrative division of the Arab Republic of Egypt for the year 2017. The village of Hegaza-Bahari is surrounded on the east by the eastern desert of Egypt, on the west by the village of Olikat, on the north by the village of AlKalahin, and on the south by the villages of Hegaza. The location of Hegaza-Bahari village in Qus Center in the Governorate of Qena according to the administrative division of Egypt 2017 is shown in figure 1. Through the use of topographic maps, scale 1: 50,000 sourced from the Egyptian Survey Authority, it was found that the village of Hegaza-Bahari faces one main watershed coming from the Red Sea Mountain ranges. The village of Hegaza-Bahari ranks second among the villages and cities of Qena governorate in terms of the number of times it was exposed to Flood Hazards in the period between 1979 and 2016, as it was exposed to flood risks 10 times in that period, about $22 \%$ of the total number of times that the villages and cities of the Qena governorate were exposed hazards from surface runoff, and there are urban expansions in the flood plains.

\section{HYDROLOGIC MODELING}

In the hydrological investigation, the maximum precipitation on the watersheds was determined. In addition, the streams and basins with their geomorphological characteristics were demarcated using integrating a hydrological model (HEC-1) with a geographic information system( GIS). This is presented, as follows: 


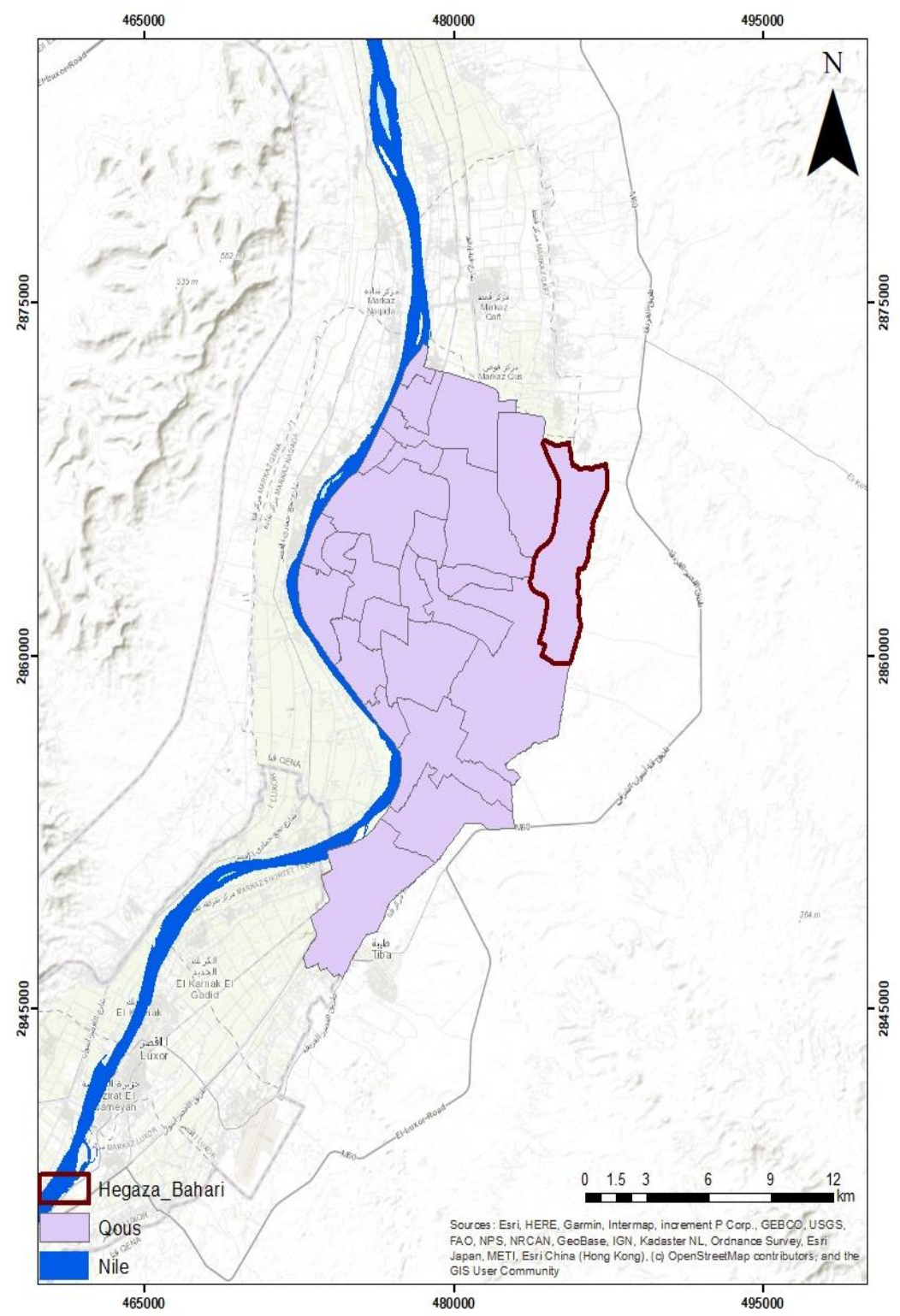

Figure 1. Location of Hegaza -Bahari village according to the administrative division of Egypt2017

\subsection{Analysis of rainfall data}

Determining the accurate data of the quantities of precipitation that fell on the watersheds is one of the most important factors that help in calculating the accumulated floods from those precipitations. In the metrological study, daily precipitation data available on globalweather.tamu.edu over the 36 years of 1979 through 2014, was used. A Weibull method was used in the statistical distributions according to the Egyptian Code for Water Resources and Irrigation Works to determine the depth of precipitation for different return periods as shown in Table 1. 
FLOODS HAZARDS ASSESSMENT BY INTEGRATING HYDROLOGIC MODELING AND A GEOGRAPHIC INFORMATION SYSTEMS (MULTI-CRITERIA DECISION TECHNIQUE)

Table 1. Precipitation depth for different return periods by Weibull method.

\begin{tabular}{|c|c|c|c|c|c|}
\hline \multirow{3}{*}{$\begin{array}{c}\text { Weather } \\
\text { station No. }\end{array}$} & \multirow{3}{*}{ Longitude } & \multirow{3}{*}{ Latitude } & \multicolumn{3}{|c|}{ Return period (Year) } \\
\hline & & & 25 & 50 & 100 \\
\hline & & & \multicolumn{3}{|c|}{ Max.24 hr. precipitation depth $(\mathrm{mm} / \mathrm{day})$} \\
\hline 1 & 32.8125 & 25.4467 & 19.7 & 25.2 & 31 \\
\hline 2 & 33.125 & 25.4467 & 22.7 & 30 & 37.8 \\
\hline 3 & 32.8125 & 25.7589 & 28.8 & 34.5 & 44.1 \\
\hline 4 & 33.125 & 25.7589 & 25.7 & 35.1 & 45.5 \\
\hline
\end{tabular}

\subsection{Extraction of drainage streams and drainage basins}

The process of determining and demarcating watersheds and basins was carried out using integrating a hydrological model (HEC-1) with a geographic information system( GIS) to obtain high-caliber hydrological modeling by the following steps:

- It fills the sinks in a raster.

- It creates a flow raster from the cell to its neighbour.

The input raster representing a continuous surface.

\section{Output flow direction raster}

The output raster that shows the flow direction from each cell to its steepest downslope neighbor. This output is of integer type.

\section{Force all edge cells to flow outward (optional)}

Specifies if edge cells will always flow outward or follow normal flow rules.

- Unchecked - If the maximum drop on the inside of an edge cell is greater than zero, the flow direction will be determined as usual; otherwise, the flow direction will be toward the edge. Cells that should flow from the edge of theso. This is the default.

- Checked-All cells at the edge of the surface raster will flow outward from the surface raster.

\section{Output drop raster (optional)}

An optional output drop raster.

The drop raster returns the ratio of the maximum change in elevation from each cell along the direction of flow to the path length between centers of cells, expressed in percentages.

This output is of floating-point type.

- It creates an accumulated flow raster to the cell.

- It optionally evaluates the raster cells.

- It denotes segment order to represent linear network

It creates a raster to delineate drainage basins in this study, digital elevation models (DEMs) with an accuracy of 30 meters were used, obtained through earthexplorer.usgs.gov. The results of the streams derived from digital elevation models are compared to watershed paths with topographic maps, scale 1: 50,000 sourced from the Egyptian Survey Authority, it turns out that there is a match between them. Streams within the Wadi Hegaza-Bahari watershed are classified using geographic information systems (GIS) into five classes, where class 5 indicates very high hazard while class 4 indicates high hazard, class 3 indicates medium hazard, class 2 indicates a low 
hazard. Finally, class 1 indicates a very low hazard as shown in figure 2. Stream's statistics of Wadi Hegaza-Bahari Watershed are shown in table 2.

\subsection{The morphological characteristics}

During the hydrological investigation, the morphological characteristics were extracted by integrating drainage streams, drainage basins and contour map; figure (3). The main drainage basin is divided into seven sub-basins as shown in figure 4. The geomorphological characteristics of these seven basins are shown in Table 3.

Table 2. Stream's statistics of watersheds affecting the village of Hegaza-Bahari

\begin{tabular}{|c|c|c|}
\hline Stream order no. & Sum_Length $(\mathbf{K m})$ & percentage\% \\
\hline 1 & 64.31 & $45.662 \%$ \\
\hline 2 & 45.54 & $32.335 \%$ \\
\hline 3 & 20.98 & $14.896 \%$ \\
\hline 4 & 5.06 & $3.593 \%$ \\
\hline 5 & 4.95 & $3.515 \%$ \\
\hline
\end{tabular}

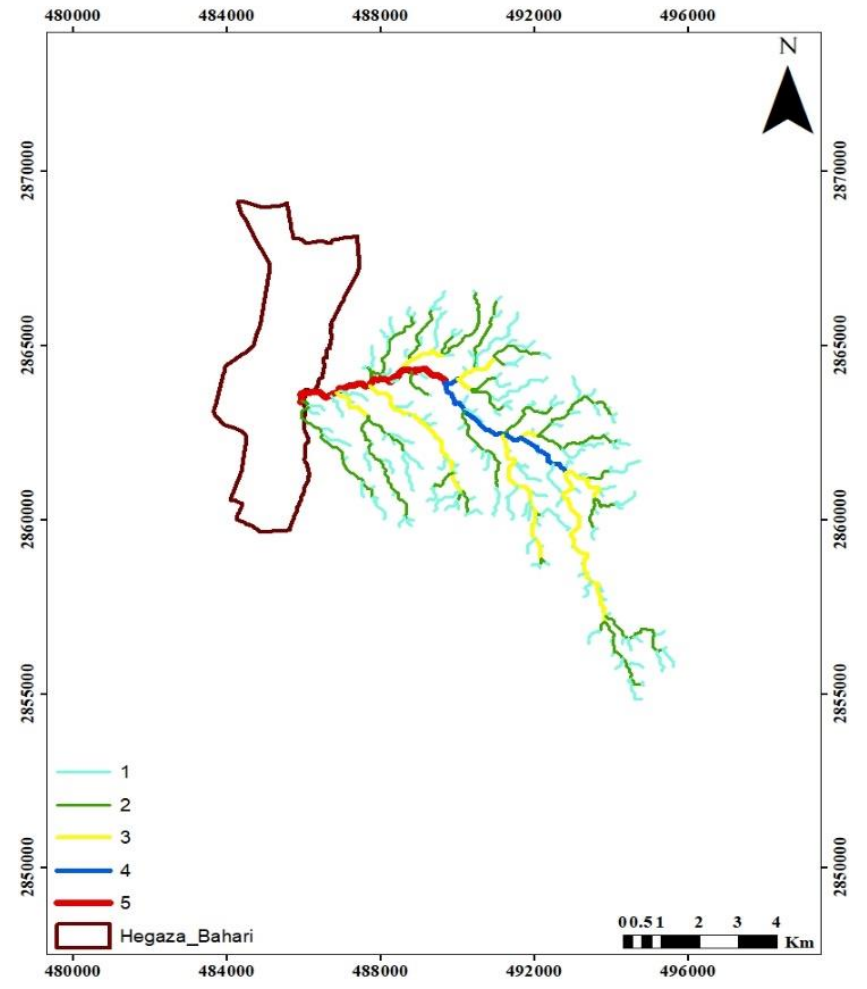

Figure 2. Classification of streams in watersheds affecting the village of Hegaza-Bahari.

Table 3. The geomorphological characteristics of sub-basins 
FLOODS HAZARDS ASSESSMENT BY INTEGRATING HYDROLOGIC MODELING AND A GEOGRAPHIC INFORMATION SYSTEMS (MULTI-CRITERIA DECISION TECHNIQUE)

\begin{tabular}{|c|c|c|c|c|c|c|c|}
\hline & \multicolumn{7}{|c|}{ Sub-Basin no. } \\
\hline Basins Data & B 1 & B 2 & B 3 & B 4 & B 5 & B 6 & B 7 \\
\hline Basin Area (km²) & 3.12 & 6.49 & 6.47 & 9.99 & 5.25 & 10.42 & 12.08 \\
\hline Basin Slope (m/m) & $\begin{array}{c}0.035 \\
5\end{array}$ & 0.0381 & 0.0348 & 0.0480 & 0.0354 & 0.0443 & 0.0456 \\
\hline Basin Length (m) & $\begin{array}{c}4261 . \\
4\end{array}$ & 4933.04 & 5129.7 & 4233.95 & 3800.04 & 4570.88 & 7788.1 \\
\hline Basin Perimeter (m) & $\begin{array}{c}15601 \\
.8\end{array}$ & 20324.4 & 24872.6 & 19922.8 & 19734 & 28062.5 & 32075.8 \\
\hline Shape Factor & 5.83 & 3.75 & 4.07 & 1.79 & 2.75 & 2 & 5.02 \\
\hline Sinuosity Factor & 0.88 & 1.09 & 1 & 1.01 & 1.01 & 1.01 & 1.07 \\
\hline
\end{tabular}

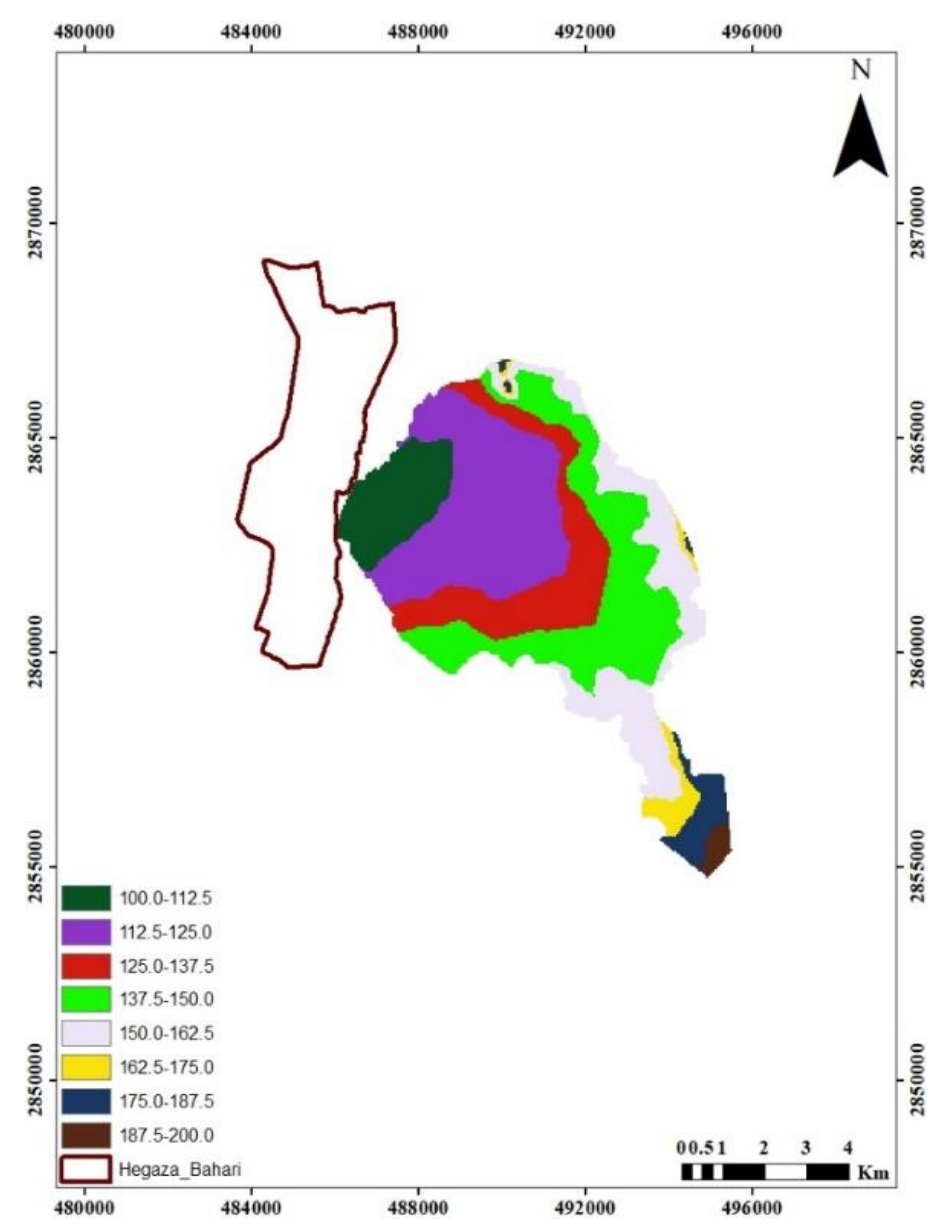


FLOODS HAZARDS ASSESSMENT BY INTEGRATING HYDROLOGIC MODELING AND A GEOGRAPHIC INFORMATION SYSTEMS (MULTI-CRITERIA DECISION TECHNIQUE)

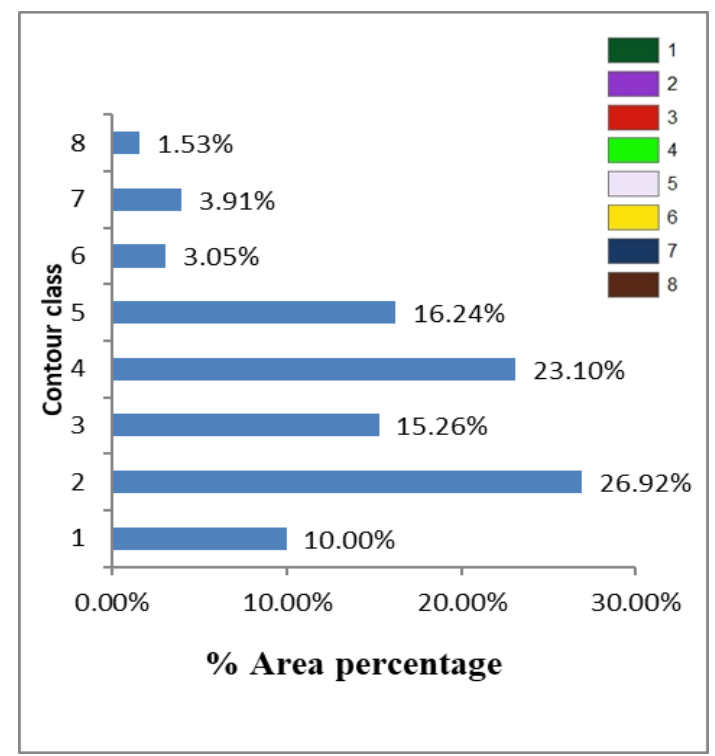

Figure 3. Contour map of Wadi Hegaza-Bahari Watershed.

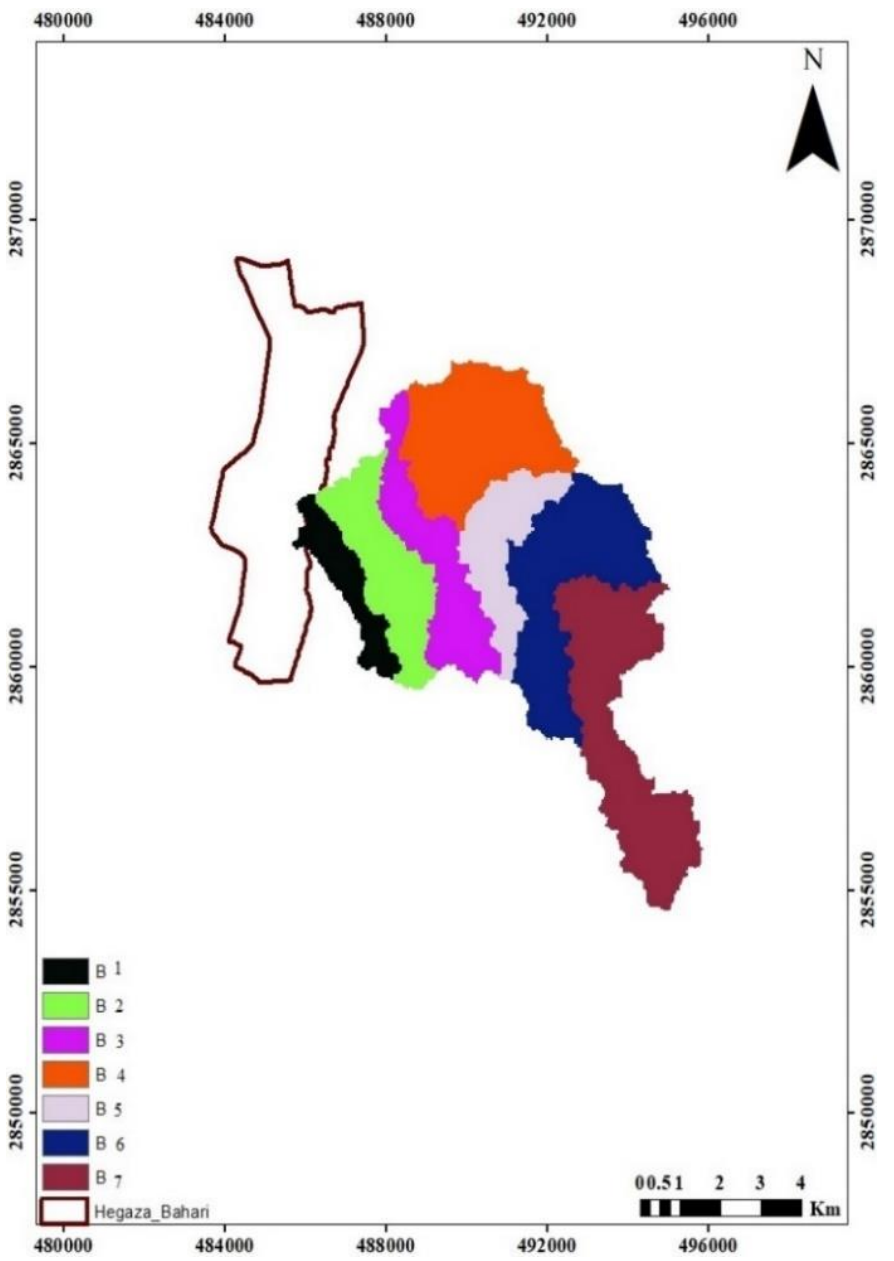

Figure 4. Sub-basins map of Wadi Hegaza -Bahari Watershed 


\subsection{Watersheds Curve Number}

Via the hydrological investigation, the effective precipitation amounts were calculated, where a mathematical method represented the rainfall losses by relating the total rainfall to the surface runoff by implementing the curve number method. This method depends on the combination of two important elements in the study area (i.e., the definition of hydrological groups and the land use). Using the GIS data, the hydrological group was combined with the land use in the hydrologic model (HEC-1) and the Watersheds affecting the Hegaza-Bahari Village, total curve number was defined to be 85 .

\section{Integrating MCDA and GIS (GIS-MCDA)}

MCDA based on GIS was implmented to identify the number of norms that influence flood hazard increment. Each norm weight was designated using AHP, where 7 criteria were signposted, as follows:

- Euclidean distance

- Slope

- Soil types
- Flow accumulation - Drainage Density

- Precipitation intensity
- Land use

The criteria are presented in figures (5) to (11).

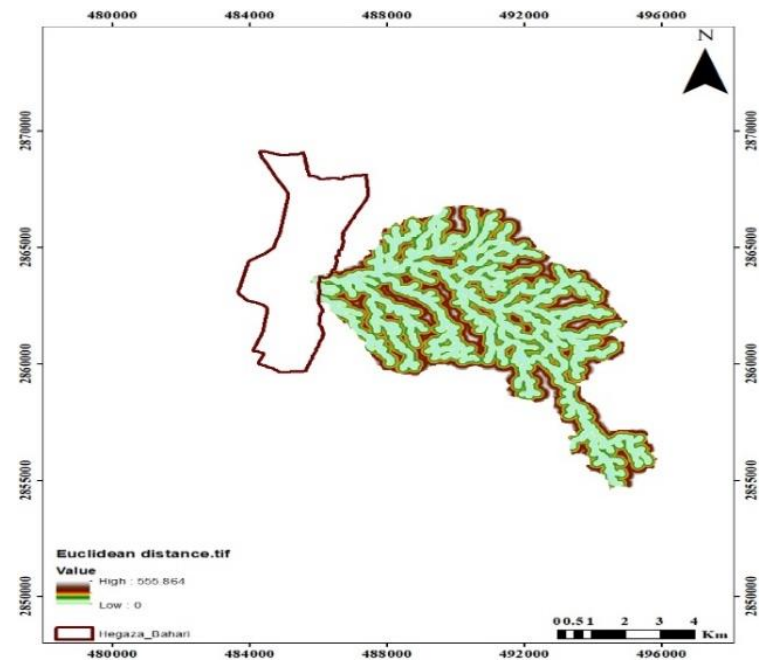

Figure 5. The Euclidean distance map.

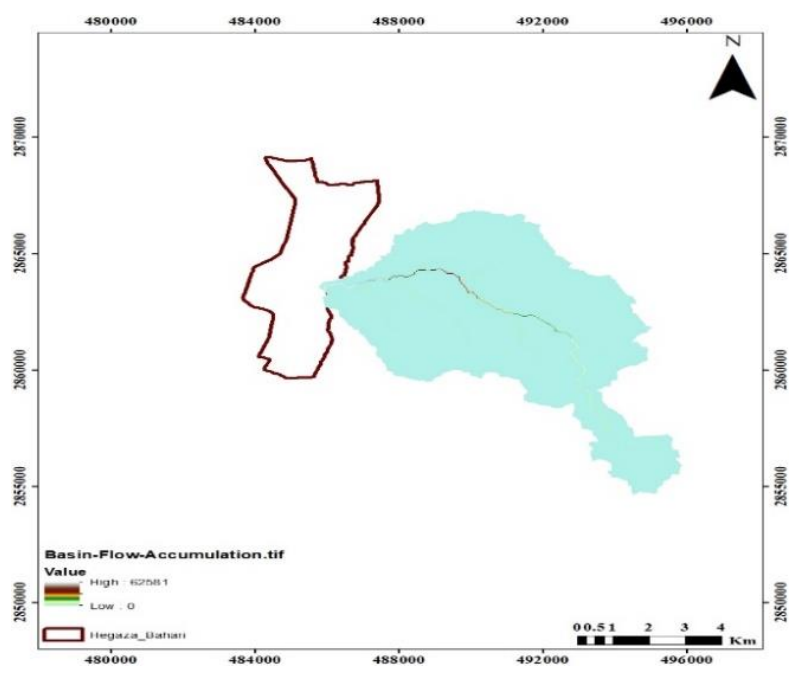

Figure 6. Flow accumulation map. 
FLOODS HAZARDS ASSESSMENT BY INTEGRATING HYDROLOGIC MODELING AND A GEOGRAPHIC INFORMATION SYSTEMS (MULTI-CRITERIA DECISION TECHNIQUE)

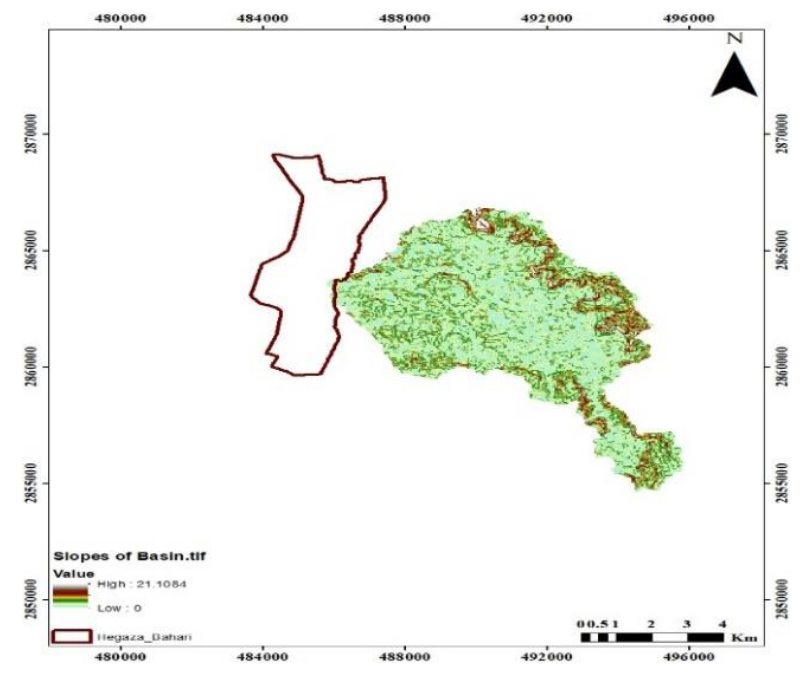

Figure 7. Slope map.

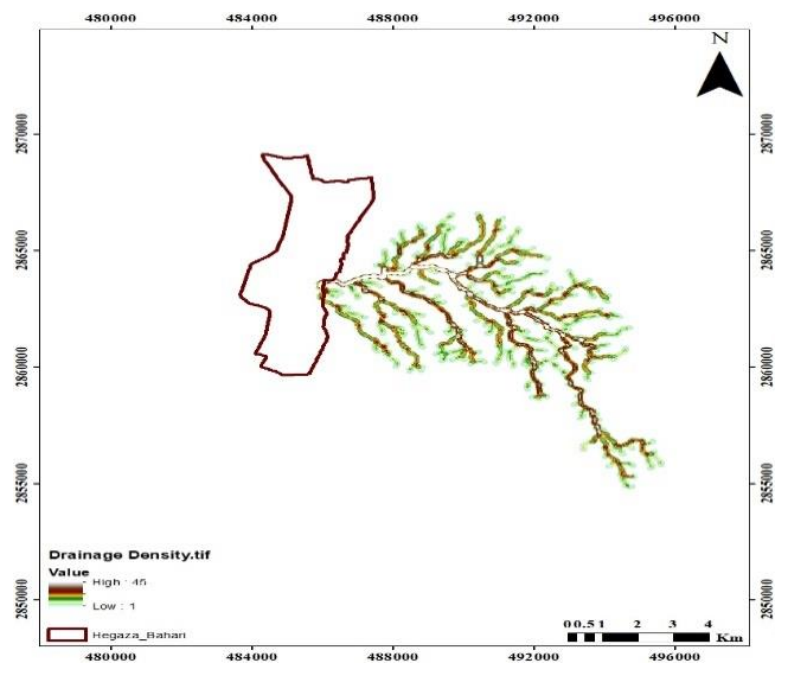

Figure 9. Drainage density map.

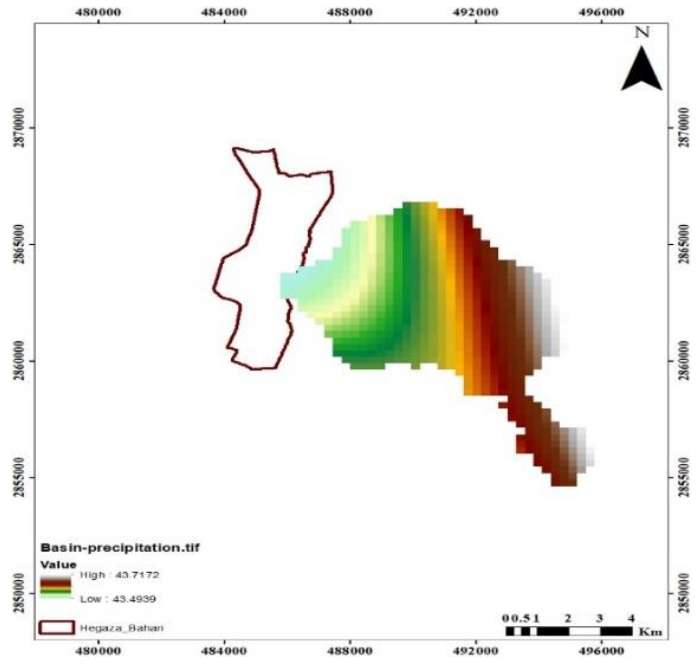

Figure 8. Precipitation intensity map.

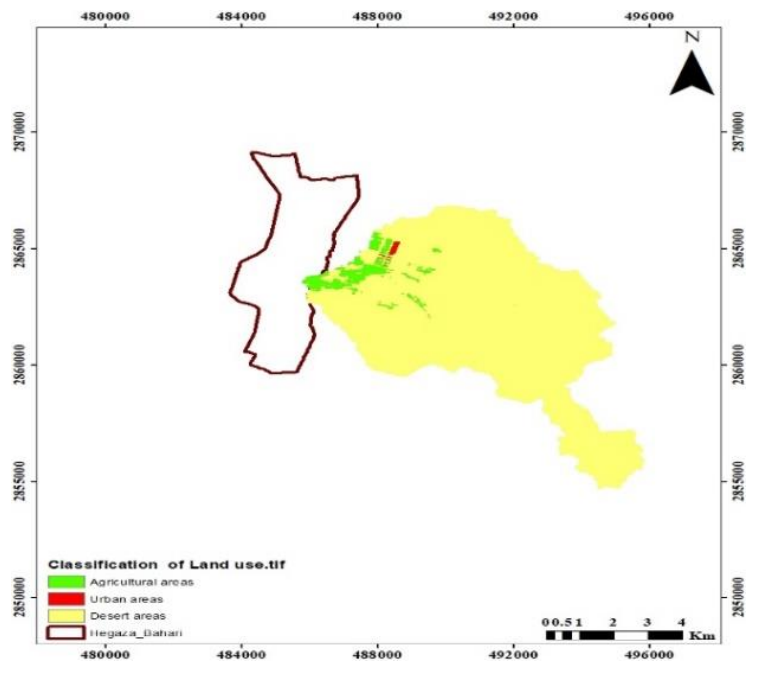

Figure 10. Land use map. 


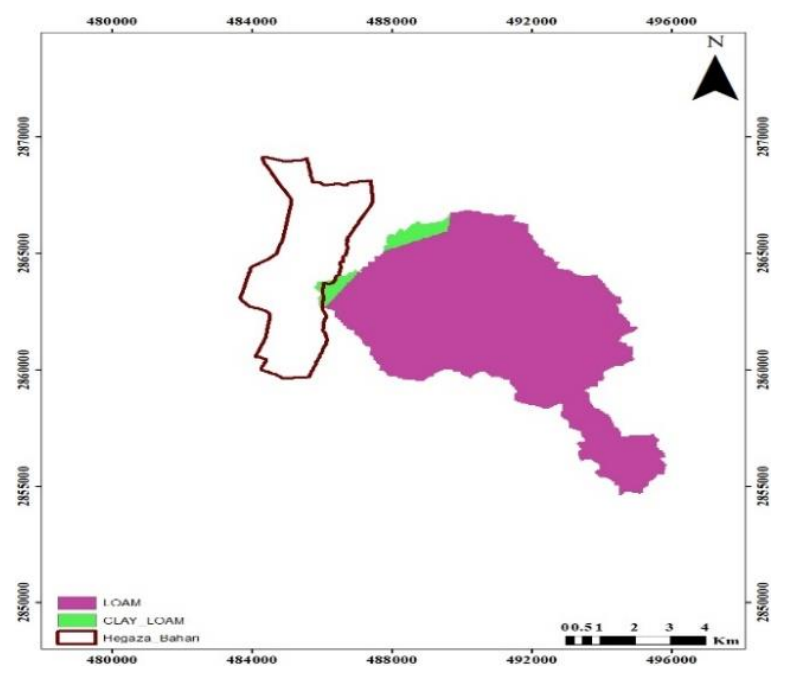

Figure11. Soil types map.

\subsection{Application of AHP}

AHP is a tool of MCDA. Thomas-Saaty put forward AHP, which is a mathematical theory. It was applied in different fields. AHP method is a hierarchical-framework. It creates the significance of every norm to the other norms. Table 4 highlights the significance of AHP norms, after Thomas-Saaty.

Table 4. The norms significane after Thomas-Saaty.

\begin{tabular}{|c|l|}
\hline $\begin{array}{c}\text { Scale/Degree of } \\
\text { Importance }\end{array}$ & \multicolumn{1}{c|}{ Explanation } \\
\hline $\mathbf{1}$ & Equal importance \\
\hline $\mathbf{3}$ & One of the criteria is of moderate importance to the other \\
\hline $\mathbf{5}$ & One of the criteria is of high importance to the other \\
\hline $\mathbf{7}$ & One of the criteria is of very high importance to the other \\
\hline $\mathbf{9}$ & One of the criteria is extremely important to the other \\
\hline $\mathbf{2 - 4 - 6 - 8}$ & $\begin{array}{l}\text { Intermediate values which used in the numerical comparison } \\
\text { between previous weights }\end{array}$ \\
\hline
\end{tabular}

The flood-hazard map was created by AHP in 4 steps, as follows:

\subsection{1 $1^{\text {st }}$ Step: Signpost the importance-values for the norms}

The $1^{\text {st }}$ step establishes the importance-values of each norm relative to others, after table 4 , in a hierarchical level. Table 5 contrasts the implemented 8 norms together with their assignedimportance. 
FLOODS HAZARDS ASSESSMENT BY INTEGRATING HYDROLOGIC MODELING AND A GEOGRAPHIC INFORMATION SYSTEMS (MULTI-CRITERIA DECISION TECHNIQUE)

Table5. Matrix of paired comparison for the norms.

\begin{tabular}{|cccccccc|}
\hline Criteri & & & & & & & \\
a & ED & FA & S & PI & DD & LU & ST \\
ED & 1.00 & 2.00 & 3.00 & 4.00 & 5.00 & 6.00 & 7.00 \\
FA & 0.50 & 1.00 & 2.00 & 3.00 & 4.00 & 5.00 & 6.00 \\
S & 0.33 & 0.50 & 1.00 & 2.00 & 3.00 & 4.00 & 5.00 \\
PI & 0.25 & 0.33 & 0.50 & 1.00 & 2.00 & 3.00 & 4.00 \\
DD & 0.20 & 0.25 & 0.33 & 0.50 & 1.00 & 2.00 & 3.00 \\
LU & 0.17 & 0.20 & 0.25 & 0.33 & 0.50 & 1.00 & 2.00 \\
ST & 0.14 & 0.17 & 0.20 & 0.25 & 0.33 & 0.50 & 1.00 \\
Total & 2.59 & 4.45 & 7.28 & 11.08 & 15.83 & 21.50 & 28.00 \\
\hline
\end{tabular}

Where:

ED: Euclidean-distance, F-A: flow-accumulation, S: slope, PI: Precipitation-intensity, DD: drainage- density, LU: land- use, and ST: soil-type.

\subsection{2 $2^{\text {nd }}$ Step: Designate the Importance-Values percentages}

Table 6 lists the Importance-Values percentages by AHP.

Table6. Importance-Values percentages by AHP

\begin{tabular}{|cccccccc|}
\hline Criteri & & & & & & & \\
a & ED & FA & S & PI & DD & LU & ST \\
ED & 0.39 & 0.45 & 0.41 & 0.36 & 0.32 & 0.28 & 0.25 \\
FA & 0.19 & 0.22 & 0.27 & 0.27 & 0.25 & 0.23 & 0.21 \\
S & 0.13 & 0.11 & 0.14 & 0.18 & 0.19 & 0.19 & 0.18 \\
PI & 0.10 & 0.07 & 0.07 & 0.09 & 0.13 & 0.14 & 0.14 \\
DD & 0.08 & 0.06 & 0.05 & 0.05 & 0.06 & 0.09 & 0.11 \\
LU & 0.06 & 0.04 & 0.03 & 0.03 & 0.03 & 0.05 & 0.07 \\
ST & 0.06 & 0.04 & 0.03 & 0.02 & 0.02 & 0.02 & 0.04 \\
Total & 1.00 & 1.00 & 1.00 & 1.00 & 1.00 & 1.00 & 1.00 \\
\hline
\end{tabular}

\subsection{3 $3^{\text {rd }}$ Step: Establish the matrix of Weight-Values}

Tables 7 and 8 present the weight-values matrices, according to norm priority.

Table 7. weight-values matrices, according to norm priority 
FLOODS HAZARDS ASSESSMENT BY INTEGRATING HYDROLOGIC MODELING AND A GEOGRAPHIC INFORMATION SYSTEMS (MULTI-CRITERIA DECISION TECHNIQUE)

\begin{tabular}{|cccccccc|}
\hline Criteri & & & & & & & \\
a & ED & FA & S & PI & DD & LU & ST \\
ED & 0.35 & 0.47 & 0.48 & 0.42 & 0.35 & 0.28 & 0.22 \\
FA & 0.18 & 0.24 & 0.32 & 0.32 & 0.28 & 0.23 & 0.19 \\
S & 0.12 & 0.12 & 0.16 & 0.21 & 0.21 & 0.18 & 0.16 \\
PI & 0.09 & 0.08 & 0.08 & 0.11 & 0.14 & 0.14 & 0.13 \\
DD & 0.07 & 0.06 & 0.05 & 0.05 & 0.07 & 0.09 & 0.10 \\
LU & 0.06 & 0.05 & 0.04 & 0.04 & 0.03 & 0.05 & 0.06 \\
ST & 0.05 & 0.04 & 0.03 & 0.03 & 0.02 & 0.02 & 0.03 \\
Total & 0.35 & 0.24 & 0.16 & 0.11 & 0.07 & 0.05 & 0.03 \\
\hline
\end{tabular}

Table 8. Norms weight-values by AHP.

\begin{tabular}{|c|c|c|c|}
\hline Criteria & Value Weight & Weight Relative & Total of Rows \\
\hline ED & 2.57 & 0.35 & 7.34 \\
\hline FA & 1.75 & 0.24 & 7.36 \\
\hline S & 1.16 & 0.16 & 7.29 \\
\hline PI & 0.76 & 0.11 & 7.17 \\
\hline DD & 0.49 & 0.07 & 7.07 \\
\hline LU & 0.33 & 0.05 & 7.05 \\
\hline ST & 0.23 & 0.03 & 7.10 \\
\hline SMax & & & 7.20 \\
\hline
\end{tabular}

\subsection{4 $4^{\text {th }}$ Step: Signpost Consistency-Verification}

A matrix is consistent, if the multiplication of every 2 values is comparable to one and if the elements of the column are mutual to those in the equivalent row. The consistency-verification is described, as follows:

Where:

$$
\mathrm{C}-\mathrm{I}=\frac{\Omega \mathrm{Max}-\mathbf{n}}{n-1}
$$

$\mathrm{n}:$ norms number.

C-I is more acceptable near 0 , which indicates its higher confidence and consistency-verification. However, the further CI goes away from o, the higher the inconsistency, where consistency-ratio is described, as follows:

Consistency-ratio $=\mathrm{C}-\mathrm{I} / \mathrm{R}$

$\mathrm{R}$ : random-index, according to Table 9.

Table 9. "N" (Matrix-order) and "R" random-index.

\begin{tabular}{|c|c|c|c|c|c|c|c|c|c|c|}
\hline $\mathrm{N}$ & 1 & 2 & 3 & 4 & 5 & 6 & 7 & 8 & 9 & 10 \\
\hline $\mathrm{R}$ & 0 & 0 & .52 & .89 & 1.11 & 1.25 & 1.3 & 1.4 & 1.45 & 1.49 \\
\hline
\end{tabular}


From the previous table, the random-index "R" is 1.3 , where 7 criteria were utilized and the consistency-verification was 0.0250.This is considered to be acceptable.

Table 10. Weights by AHP.

\begin{tabular}{|c|c|c|c|}
\hline Criteria & Total of Rows & Relative Weight & Weight (in \%) \\
\hline ED & 2.45 & 0.35 & $35.04 \%$ \\
\hline FA & 1.66 & 0.24 & $23.75 \%$ \\
\hline S & 1.11 & 0.16 & $15.90 \%$ \\
\hline PI & 0.74 & 0.11 & $10.56 \%$ \\
\hline DD & 0.49 & 0.07 & $6.96 \%$ \\
\hline LU & 0.32 & 0.05 & $4.62 \%$ \\
\hline ST & 0.22 & 0.03 & $3.18 \%$ \\
\hline Total & 7 & 1.00 & $100.00 \%$ \\
\hline
\end{tabular}

\section{RESULTS AND DISCUSSION}

By integrating the data analyzes previously explained in hydrological modeling, it is possible to obtain calculations of the discharge and volume of the surface runoff at the outlet of the watershed affecting the village of Hegaza- Bahari. The hydrographs by HEC-1 at the outlet of the watershed for different return periods as shown in figure 12. The seven criteria used in this study were combined according to the weight of each criterion calculated by AHP in the GISModelBuilder as shown in figure 13 to produce a flood hazards map shown in figure 14.

Hazards within the Wadi Hegaza-Bahari watershed are classified using geographic information systems (GIS) into five classes, where class 5 indicates very high hazard (its area is. $0.4 \%$ of the total area) while class 4 indicates high hazard (its area is. $2.5 \%$ of the total area), class 3 indicates medium hazard (its area is. 10\% of the total area), class 2 indicates a low hazard (its area is. $37 \%$ of the total area). Finally, class 1 indicates a very low hazard (its area is. 50.1\% of the total area).

Flow vs. Time

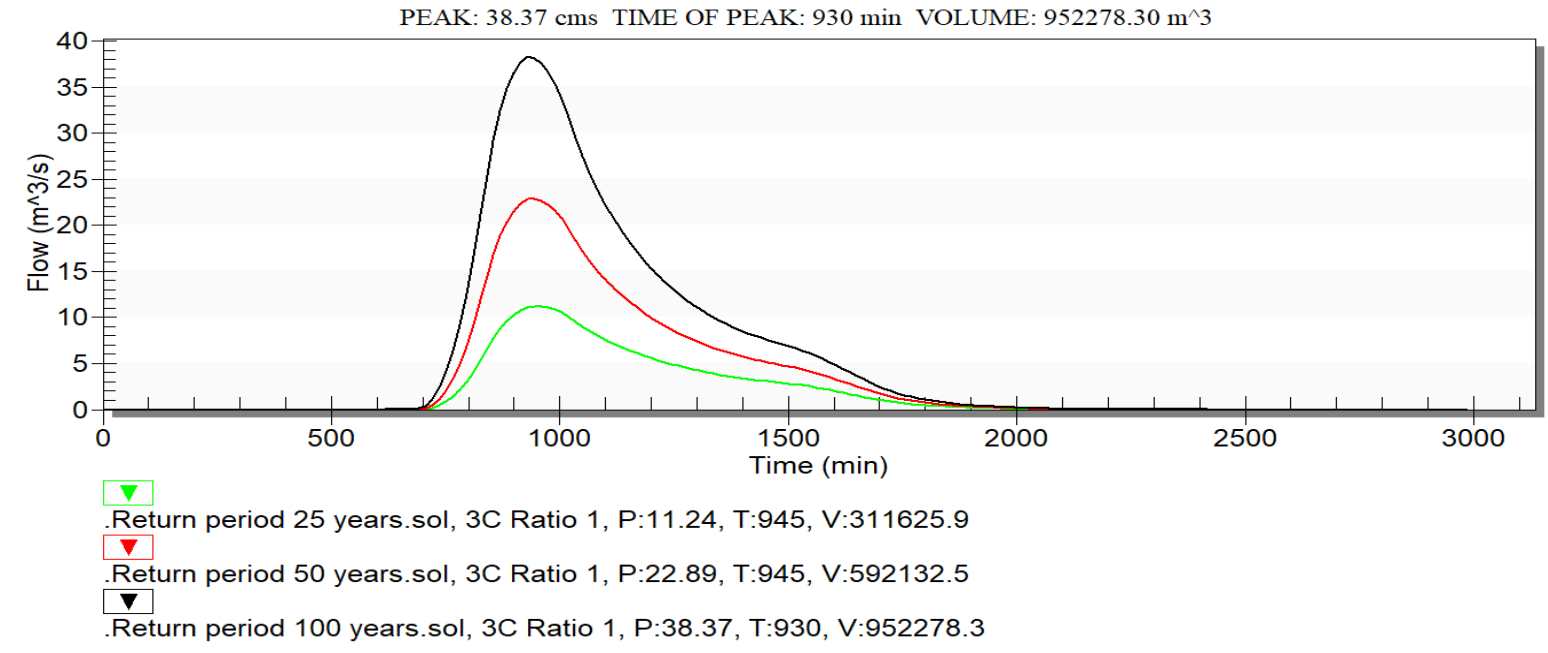

Figure 12. Hydrographs at watershed outlet for different return periods by HEC-1 


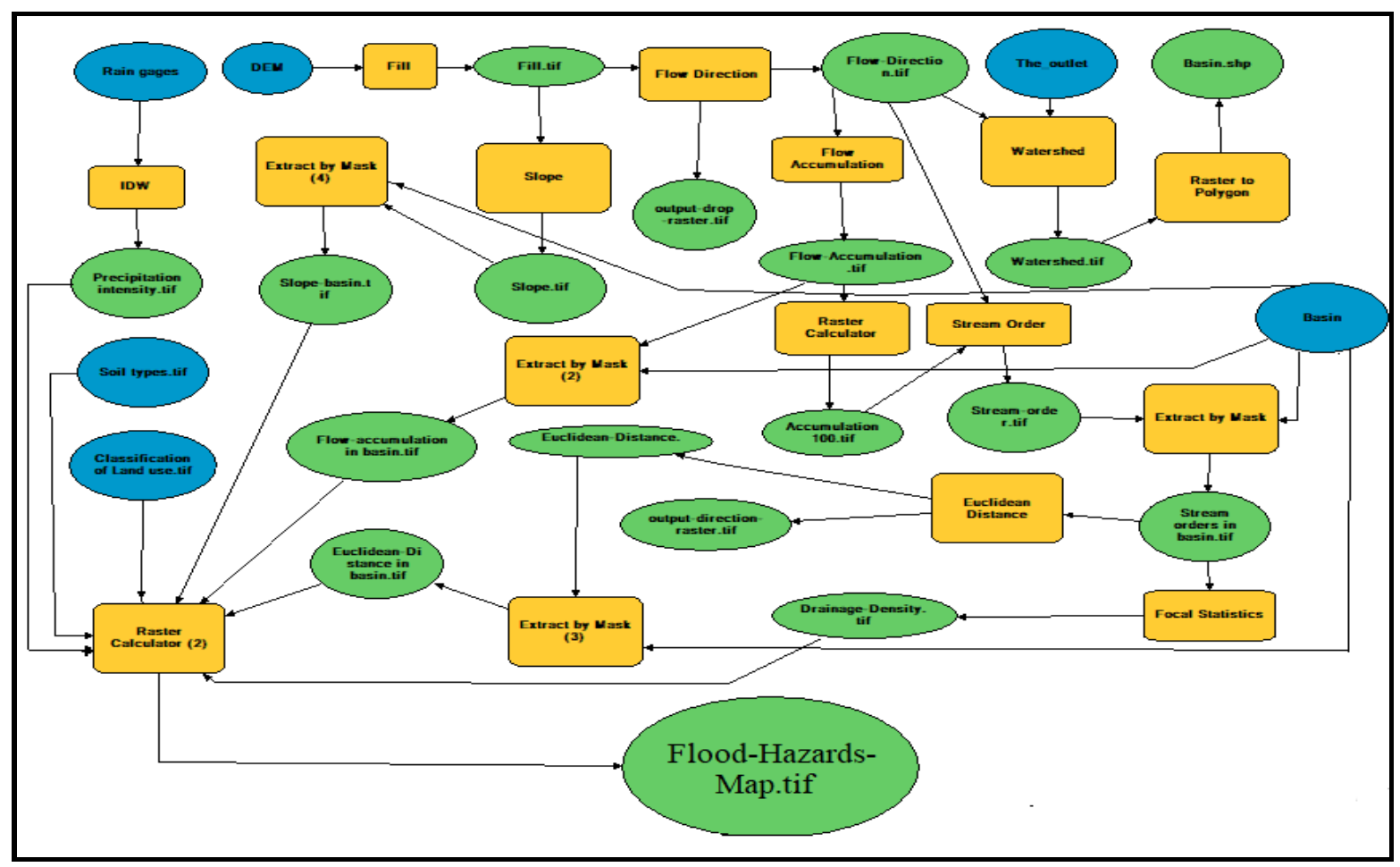

$\underset{480000}{\text { Figure 13. GIS-MCDA and flood hazards map. }} \underset{484000}{4980000}$

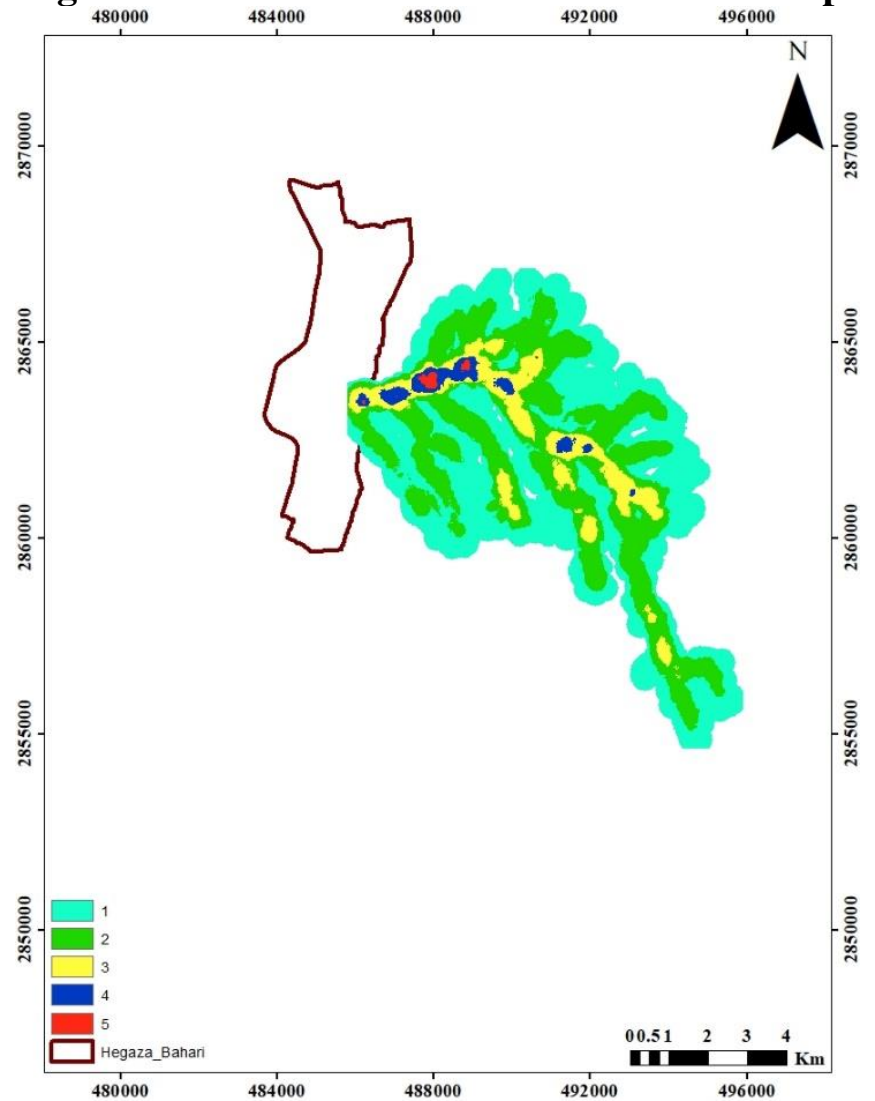

Figure 14. Flood hazard in Hegaza-Bahari Village. 
FLOODS HAZARDS ASSESSMENT BY INTEGRATING HYDROLOGIC MODELING AND A GEOGRAPHIC INFORMATION SYSTEMS (MULTI-CRITERIA DECISION TECHNIQUE)

\section{CONCLUSION}

Based on the obtained results, the following conclusions were deduced:

- MCDA integrated with GIS-MCDA visualized local flood hazard assessment mapping that will assist decision-makers in the execution of flood hazard management activities.

- Mapping the flood hazard index will contribute in planning safe areas, which will achieve the sustainable urban development, in terms of Egypt Vision 2030.

- WMS (HEC-1) has a high capacity for extracting drainage streams, drainage basins, and morphological characteristics.

- The maximum discharge value was calculated throughout 25- 50-100 year.

- Modelbuilder visualized Hegaza-Bahari Village as a watershed coming from Red Sea Mountain with an area of $53.82 \mathrm{~km}^{2}$.

- Total length of streams that affect Hegaza-Bahari Village is $140.84 \mathrm{~km}$.

- The obtained results will assist flood hazards management activities and will contribute in rehabilitating watersheds to withstand flood disasters.

\section{REFERENCES}

[1] Al-Abadi, A.M., Shahid, S., Al-Ali, A.K., 2016. A GIS-based integration of catastrophe theory and analytical hierarchy process for mapping flood susceptibility: a case study of Teeb area, Southern Iraq. Environ. Earth Sci. 75, 687. doi:10.1007/s12665-016-5523-7

[2] Andi, Besse., Martiwi, Setiawati., Abu Bakar, Sambah., Fusanori, Miura., (2017), "Physical Flood Vulnerability Mapping Applying Geospatial Techniques in Okazaki City, Aichi Prefecture, Japan", Urban Sci.

[3] Billa, L., Shattri, M., Mahmud, A. R., Ghazali, A. H., (2006), “Comprehensive planning and the role of SDSS in flood disaster management in Malaysia", An International Journal.

[4] Bubeck, P., Botzen, W., Aerts, J., (2012), "A review of risk perceptions and other factors that influence flood mitigation behavior", Risk Analysis

[5] de Brito, M.M., Evers, M., 2016. Multi-criteria decision-making for flood risk management: a survey of the current state of the art. Nat. Hazards Earth Syst. Sci. 16, 1019-1033. doi:10.5194/nhess-16-1019-2016

[6] Elmoustafa, A.M., Farres, H.N., Elfawy, M.M., 2015. Effect of Elevation Data Accuracy on Storm Drainage Schemes, Lagos , Nigeria 433-441.

[7] EU IPA 2010 TWINNING PROJECT, 2010. the preparation of the Flood Risk Management Plans.

[8] Gericke, O., Plessis, J. Du, 2012. Catchment parameter analysis in flood hydrology using GIS applications. J. South African Inst. Civ. Eng.

[9] Ghabayen, S.M., Salha, A. a, 2013. Crop Water Requirements ( CWR ) Estimation in Gaza Strip Using ArcMap-GIS Model Builder. Ijetae 3, 291-299. 
[10] Kazakis, N., Kougias, I., Patsialis, T., (2015), “Assessment of flood hazard areas at a regional scale using an index-based approach and analytical hierarchy process, application in Rhodope-Evros region, Greece", Science of the Total Environment.

[11] Khabat, K., Ebrahim, N., Edris, M., Hamid, R. P., (2016), “A GIS-based flood susceptibility assessment and its mapping in Iran, a comparison between frequency ratio and weights-ofevidence bivariate statistical models with multi-criteria decision-making technique",Natural Hazards.

[12] Kourgialas, N.N., Karatzas, G.P., 2016. A flood risk decision making approach for Mediterranean tree crops using GIS; climate change effects and flood-tolerant species. Environ. Sci. Policy 63, 132-142. doi: 10.1016/j.envsci.2016.05.020

[13] Magesh, N.S., Chandrasekar, N., 2012. A GIS based automated extraction tool for the analysis of basin morphometry. Bonfring Int. J. Ind. Eng. Manag. Sci. 2. Special Issue Spec. Issue Geospatial Technol. Dev. Nat. Resour. Disaster Manag.

[14] Olga, P., Nerantzis, K., Ioannis, K., Thomas, P., Nicolaos, T., Konstantinos, V., (2018), "Assessing Flood Hazard at River Basin Scale with an Index-Based Approach: The Case of Mouriki”, Greece, Geosciences.

[15] Omran, A., SCHRÖDER, D., RAYES, A. EL, GERIESH, M., 2011. Flood Hazard Assessment in Wadi Dahab, Egypt Based on Basin Morphometry Using GIS Techniques. gispoint.de.

[16] Somaiyeh, K., Mehran, M., (2017), "Assessment of Flood Hazard Zonation in A Mountainous Area Based on GIS and Analytical Hierarchy Process", Carpathian Journal of Earth and Environmental Sciences.

[17] Song, Y.; Ming, H.; Che, H.; Ling, F. The Damage Assessment of Flood Risk Transfer Effect on Surrounding Areas Arising from the Land Development in Tainan, Taiwan. Water 2018.

[18] Wahlstrom, M., Guha-Sapir, D, (2017), "the human cost of weather-related disasters", UNISDR, CRED, Geneva, Switzerland. 